\title{
Model of Penetration of Character Values Based on Batak Toba Culture
}

\author{
Pardomuan Simanullang \\ School of Postgraduate \\ Universitas Negeri Medan, Indonesia \\ E-mail : simanullangpardomuan@gmail.com
}

\begin{abstract}
This article aims to find out the modeling model of cultural values based on Batak Toba Batak culture developed at SD Negeri173403 Doloksanggul. This qualitative research approach supported by quantitative data to sharpen the analysis. Data collection was obtained through interviews, observation, document review, and questionnaire distribution. Respondents consist of school leaders, fourth grade teachers, and students. The result of this research shows that the modeling of the values of character of elementary school students based on the Batak toba culture in the learning activity is by inserting some activities containing Batak toba cultural values such as tor-tor and batak songs that foster motivation on the students character, as well as the principles of Batak Toba that is the na tolu submission which is submitted through the proverb or basa and also the story of Batak Toba. It was concluded that the students of SD Negeri173403 Doloksanggul were one of the schools that developed the model of cultural values based on Batak Toba. The development of moral character in schools has a goal to create a fun school climate and ecosystem for all the citizens of the school and the bigger goal is to nurture the nation's character to avoid bad behavior of school students who are inconsistent with the culture and character of the nation. Such as: street fights, engaged in promiscuity and drugs. This type of research is research and development $(R \& D)$.
\end{abstract}

\section{Keywords - Character Value, Batak Toba Culture}

\section{INTRODUCTION}

The moral character education is one of the teaching program at school that has a purpose to develop the attitude of the students by comprehending the values and the society beliefs as the morality power in their life through the honesty, trustworthiness, discipline, and cooperation that emphasizes the affective areas ( feeling and attitude) without leaving cognitive areas ( rational thinking) and Skills/ Psychomotor ( the skill in managing data, expressing opinions, and the cooperation.

In the Regulation of the Minister of Education and Culture No. 23 of 2015 about the growth of the character has been affirmed that the character education must be applied in the academic year 2015/2016. The growth of the character in schools has a goal to create a pleasant school climate and ecosystem for all people at the school and the bigger goal is to grow the children's character of our nation. It is the time to grow the moral character in every school through series of mandatory activities, general habituation, and periodic habituation as the new way to develop the moral character.

In order to increase the learner's success in shaping the mental, moral, spiritual, personal, and social, the application of moral character education can use various approaches by choosing the best approach (elective) and each other mutually linking in order to produce the optimal results (synergistic). The following approaches are :

1. Inculcation Approach

2. Cognitive Moral Development Approach

3. Values Analysis Approach

4. Values Clarification Approach

5. Action Learning Approach

Lately, often happening a phenomenon of the bad behavior of school students who are not in suitable with the national culture and character. For example, the students' fighting, involved in promiscuity and drugs. Student incompetence can be seen from the behavior of students who are lack to respect the social environment, prioritize the egoism rather than make a harmony and social harmony that threatens the integrity of the nation. Thus, it is necessary to develop the values of Batak Toba culture in the learning of moral character which is effective to improve the character education in schools by preparing the lesson materials that can be one of the main learning sources of teaching and learning activities in the development of student character in school either in media and teaching materials forms. To measure the students' ability to comprehend the values of Batak Toba culture in the learning of moral character combined with quantum teaching approach.

\section{BASIC THEORY}

\subsection{Understanding The Moral Character Education}

The moral character education operationally is the effort to prepare the students by a guidance, a teaching and practicing as long as the growth of themselves as the stock for their future, so that they have a clear conscience, to behave well, and to keep morals in performing obligations to God and human beings. Thus, the formation of a whole 
person is reflected in the behavior of speech, deeds, attitudes, thoughts, feelings, work and work based on the values of religion and the noble norm and moral of the nation.

The moral character values are as the expected attitude, must be owned by the students as the basic of their personal performing. According to competency based curriculum, the moral character lesson grade 1 until 6 , the values are :(1) Believing in the existence of God and always obeying His teachings, ,(2) Owning and developing tolerance, Self-esteem, (3) Growing self-discipline, (4) Having a sense of responsibility, (5) Able to think positively, (6) Developing self potential, (7) Growing love and affection, (8) Having a solidarity, (9) Having mutual respect, (10) Growing honesty

\subsection{The Purpose of The Moral Character Education}

The purpose of the moral character education are as follows:

1. Students understand the values of character in the family, local, national, and international environment through customs, laws, and order among nations.

2. Students are able to develop the character or character consistently in making moral decisions in the midst of the complexity of life in the society today.

3. Students are able to face real problems in society rationally for the best decision-making after taking consideration in accordance with the norm of manners.

4. Students are able to use a good character experience for the formation of awareness and behavior patterns that are useful and responsible for their actions.

\subsection{Batak Toba Cultural Values}

The culture according to Koentjaraningrat (1993, pp. 9) is a whole system of ideas and human works that must be familiarized with learning, along with the overall result of his mind and his work. From the definition can be concluded that culture is the values that are owned in a society, socialized, and shaping a person's attitude in life. Value is something that gives meaning to life, reference, the starting point and purpose of life. Values are something that is upheld. Color values animate and concern one's mindset and actions. This is in line with Hill's opinion (1991, p.15): "When people speak of values, they are usually referring to those beliefs held by the individuals to which they attach special priority or worth, and where they tend to order their lives".

Vergouwen (2004, p.1) says "The patrilineal kinship system that forms the backbone of the Batak community, comprising derivatives, clans, and tribal groups, all interconnected along male lines."

Batak Toba cultural values consist of belief in God which before the entry of Christianity to the land of Batak manifested in the division of three banua. Banua is the upper continent, the middle continent, and the lower continent. It is also seen in the ornament that is in Batak traditional house. After that Dalihan Natolu, Patik dohot Uhum (provisions and Laws), Hamajuon (progress). Hamoraon (wealth), Hagabean (many offspring /prosperity), Hasangapon (glory), with Marsiadapari (mutual cooperation).

Then the Toba Batak cultural values can be divided into two major parts of soft culture and hard culture. Soft Culture consists of: (1) Marga (identity of), (2) Patik dohot Uhum (provisions and laws), (3) Hamajuon (spirit to advance), (4) Marsidapari (the spirit of cooperation, manifested in working the fields) (5) Dalihan Natolu (the concept of furnace nan three which is a kinship system) Hamoraan (wealth) hagabean (welfare), Hasangapan (glory) which is the purpose of life Batak Toba society. Hard Culture consists of: (1) Folklore: Sigale-gale, (2). Dance: Tor-tor, (3) Regional songs, (4) Musical instruments: Gondang, (5) Language and Proverbs Batak Toba, Umpasa, (6) Game: Marsilelean, (7) Traditional clothing: Ulos, ( 8) Traditional house: House

With the foundation of national cultural values that will be developed, the cultural values of Toba Batak can be explored for the process of developing the national insights of learners that is from the regional songs, ulos, tor-tor, and folklore because there are values contained in it. While Hamoraon (wealth), hagabean (many offspring and prosperous) and hasangapon (glory) that is the values of hard work, persistence, and responsibility. The value of hamajuon (progress) hard work, creativity and discipline. While from patik dohot uhum is honesty, sense of justice, and discipline. While from dalihan natolu that is cooperation, tolerance, appreciation, and responsibility.

\section{METHODOLOGY}

Data collection was conducted in 2017 with the target of the study of SD Negeri173403 Doloksanggul. The research method used a qualitative approach, to support or refine the analysis using quantitative data. Qualitative data collection is done by interview method, observation and document review, and quantitative data collection by filling in questionnaire given to fourth grade students who have implemented the 2013 curriculum that is 1 class IVA and 1 class IVB.This collection of qualitative data not only collect data but also an approach to the empirical world. The term qualitative itself refers to a broad understanding of research that produces a descriptive, ie in the form of words and behavior of students who can be observed, both orally and factually, and analyzing and interpreting the data in the study. Interviews were conducted with Principals, fourth grade Teachers, and Students. Observations were made on student behavior during school and focused on intra and extracurricular activities. 


\section{DISCUSSION}

The development procedure which is taken to produce the learning model product is divided into 4 (four) stages, they are : 1) the first stage of Problem and Needs Analysis, 2) the second stage of Model Design and Preparation of the Textbook, 3) the third stage of Review by Cultural Expert and Character , 4) the fourth stage of the Early Design of the Learning Model and Textbook. In accordance with the theme of class IV, the responsibility affirms to students' attitude and behavior of a person to carry out his duties and obligations, which he should do, to himself, society, environment (natural, social and cultural), the state and God Almighty. So, the cultural values of Batak Toba also need to be contained in it that is Hamoraon (wealth), Hagabean (many descendants and prosperous) and hasangapon (glory) that is hard work values, perseverance and responsibility. The value of hamajuon (progress) hard work, creative and discipline. While from patik dohot uhum is honesty, sense of justice, and discipline. While from dalihan natolu, those are cooperation, tolerance, appreciation and responsibility.

\section{Batak Toba Cultural Values Table as a source of the Moral} Character learning

Dalian natolu, Marsiadapari (Having an attitude that always wants to help friends and people around him). The process of activities carried out according to the steps.

The steps on this method are:

\section{a. Interest growth ( $T=$ Grow interests $)$}

Include the students by enticing their hearts. In this stage, it can be done by rolling the seats at each meeting, attaching the pictures, the video (The story of parents working hard in the fields to send their children to school) to foster interest and motivation of students for their duties and responsibilities as children at home and at school as well in its environment.

\section{b. General experience sharing $(A=$ Natural $)$}

In this step, the teacher provides students with the opportunities to share experiences students have experienced in relation to the responsibilities they have already undertaken. The activities of the students are: Telling about the observed images, and relating them to experiences related to the cultural values of the natolu dalihan, namely cooperation, tolerance, respect and responsibility. The teacher also explores students' experiences by giving questions in the form of batik (umpasa) which mean responsibility and the students answer it by translating it into Indonesian

\section{c. Naming or presenting the material $(N=$ Name $)$}

Naming satisfies the brain's natural desire to identify, sort, and define. Naming is built on the knowledge and curiosity of students at the time. In this activity, the teacher conveys the material to be studied completely after the students tell the experience that has been obtained, then the students make a naming of the actions as the responsibility they have done. so in the naming of students already have the provision and mastery of the material more leverage.

\section{d.Demonstrating student knowledge $(D=$ Demonstration $)$}

Demonstration is done by giving opportunity to the student to present the result of independent duty which has been given by the teacher before, either to the group's friends or to all students. Students demonstrate in front of Tor-Tor class and Batak songs entitled anak na burju and inang na burju which means the attitude of a child who is responsible to parents at home, friends in school, and in the environment. .

\section{e. Repetition is done by students ( $U$ = Repeat $)$}

Reviewing the material presented by the teacher, how to tell the group's friends, or to all students and teachers will appoint one of the students to re-explain the material that has been given by explanation and or by directly practicing the forms of responsibility that have been discussed earlier in tor-tor shapes, Batak songs, and batik quote (for example).

\section{f. Celebration of student's effort $(R=$ Celebrate $)$}

Giving praise to successful and unsuccessful students who answer questions and do not directly blame the inappropriate student's answers, other than that the celebration is done by applauding together when the lesson ends.

\section{RESULT}

This chapter describes how the map of character values students Negeri173403 Doloksanggul that has been through the planting of the cultural values of Batak Toba through planting the belief of God Almighty and always obey His teachings, Complying with the teachings of religion, Owning and developing the attitude of tolerance, self-esteem, self-discipline, developing work ethic and learning, Having a sense of responsibility, Having a sense of openness, Able to think positively, Developing self potential, Growing love and affection, Having togetherness and mutual cooperation, Having a sense of solidarity, Mutual respect, etiquette and manners, Have a sense of shame, Cultivate honesty. While to compare 10 character values, which character approach has a higher value, that is by making scale and then categorized, in the hope that the result can be explained through narrative (qualitative). The categories of character values are grouped into five namely: 
TABLE 1. TEN OF THE FOLLOWING CHARACTER VALUES

\begin{tabular}{|l|l|c|c|c|c|}
\hline No & Character & \multicolumn{2}{|c|}{ Class } & \multirow{2}{*}{$\begin{array}{l}\text { Combine } \\
\text { of } \\
\text { IV A dan } \\
\text { IV B }\end{array}$} & $\begin{array}{l}\text { Cate } \\
\text { Gory }\end{array}$ \\
\cline { 3 - 5 } & & IVA & \multicolumn{1}{|l}{ IVB } & & SB \\
\hline 1 & $\begin{array}{l}\text { Obeying His } \\
\text { teachings }\end{array}$ & 4,15 & 3,89 & 4,02 & SB \\
\hline 2 & $\begin{array}{l}\text { Have an } \\
\text { attitude of } \\
\text { tolerance }\end{array}$ & 4,62 & 3,93 & 4,28 & MK \\
\hline 3 & $\begin{array}{l}\text { Develop work } \\
\text { ethos }\end{array}$ & 3,95 & 3,78 & 3,86 & SB \\
\hline 4 & Responsibility & 4,29 & 3,98 & 4,14 & MK \\
\hline 5 & Self-discipline & 3,89 & 3,23 & 3,56 & SB \\
\hline 6 & Compassion, & 4,88 & 3,98 & 4,43 & MK \\
\hline 7 & $\begin{array}{l}\text { Mutual } \\
\text { cooperation }\end{array}$ & 4,54 & 3,24 & 3,89 & SB \\
\hline 8 & Mutual respect & 4,28 & 3,92 & 4,1 & MK \\
\hline 9 & Polite & 3,95 & 3,82 & 3,88 & MK \\
\hline 10 & Honest & 3,97 & 3,25 & 3,61 & \\
\hline
\end{tabular}

The sample used is respondents Negeri173403 Doloksanggul class IV amounting to 68 Of that number is divided from the students of the class IVA (35 students) and the class IVB (33 students). The average value of student characters in the Country 173403 Doloksanggul quite encouraging.

From the table it can be seen that based on his statement, the students of SD Negeri173403 Doloksanggul in general already have a commendable character. Learners have started to civilize the attitude of high work ethic, discipline, polite and honest attitude. While the character of religious attitude, honest, tolerant, high work ethic, Responsibility on duty has become a school culture. Religious attitude of the students of Negeri 173403 Doloksanggul get value of 4,15, that is, activities that are religious in nature embedded in students (already started to cultivate). When distinguished for classes IVA and IVB, evidently classes IVA higher value compared to the class IVB. Of the 10 lowest characters owned by students of the IVA class is a high work ethic, discipline, courtesy and honest attitude. The value is still in the category began to entrenched. For the class IVB the lowest characters are self-discipline, Mutual cooperation, and honest, still in the new category began to develop.

TABLE 2. SCALE AND CATEGORY OF VALUE OF CHARACTER

\begin{tabular}{|c|c|}
\hline SCALE & CAT EGORY \\
\hline $1-1,75$ & Not yet Seen (BT ) \\
\hline $1,76-2,50$ & Begin Visible (MT) \\
\hline
\end{tabular}

\begin{tabular}{|c|c|}
\hline $2,51-3,26$ & Begin Developing (MB) \\
\hline $3,27-4,0$ & Begin to cultivate (MK) \\
\hline $4,1-5.0$ & Being a school culture \\
& $(\mathrm{MB})$ \\
\hline
\end{tabular}

\section{CONCLUSIONS}

Batak Toba cultural values are in great demanded by students in learning The Moral Character Lesson, at grade IV SD. It can be seen from the way they receive lessons of the character K13. The students are very serious and more meaningful of the subjects because the cultural values of batak toba are contained in the subjects of the moral character. It is a real thing they accept and have been used to hear them in their daily life .This assessment is packed with the approach of quantum teaching which is known by the term T-a-n-d-u-r so that makes learning more fun for learners. Related character, Student Affairs 173403 Doloksanggul has continuously shown high work ethic attitude, discipline, politeness and honest attitude, religious, honest, tolerant, high work ethic, responsible on duty.

\section{REFERENCES}

[1] Bogdan,R.C.,\& Biklen,S.K (2007). Qualitative research for education. An introduction to theory and method. ( $5^{\text {th }}$ ed). Boston: Pearson

[2] Dick, W. \& Carey, L. (2009). The systematic design of instruction. $\left(5^{\text {th }}\right.$ ed.). New York: Harper Collins Publishers.

[3] Gustafson, Kent L. 1981. Survey of Instrucyional Development Models. Syracuse, NY: Eric IR Document.

[4] Hergenhahn, B.R \& Olson, M.H. 2008. Theories of learning. Jakarta: Kencana

[5] Hughes,1991. Teachers' professional development. Melbourne, Victoria: Australian Council for Educational Research.

[6] Isman, A. (2012). Effectiveness of instructional design model (ISMAN - 2011) in developing the planning teaching skills of teachers college students' at King Saud University. The Turkish Online Journal of Educational Technonlogy. January 2012, Volume 11, Issue 1

[7] Schein, E.H. (2010). Organizational culture and leadership. (4 $4^{\text {th }}$ ed).. San Fransico: Jossey-Bass.

[8] Sinaga, Bornok. (2007). Pengembangan Model Pembelajaran Matematika Berdasarkan Masalah Berbasis Budaya Batak. (DISERTASI). Surabaya. Universitas Negeri Surabaya.

[9] Twelker, P. A., dkk. 1972. The Systematic Development of Instruction. An. Overview and Basic Guide to The Literature. Stanford: The ERIC Clearinghouse on media and Technology. 
